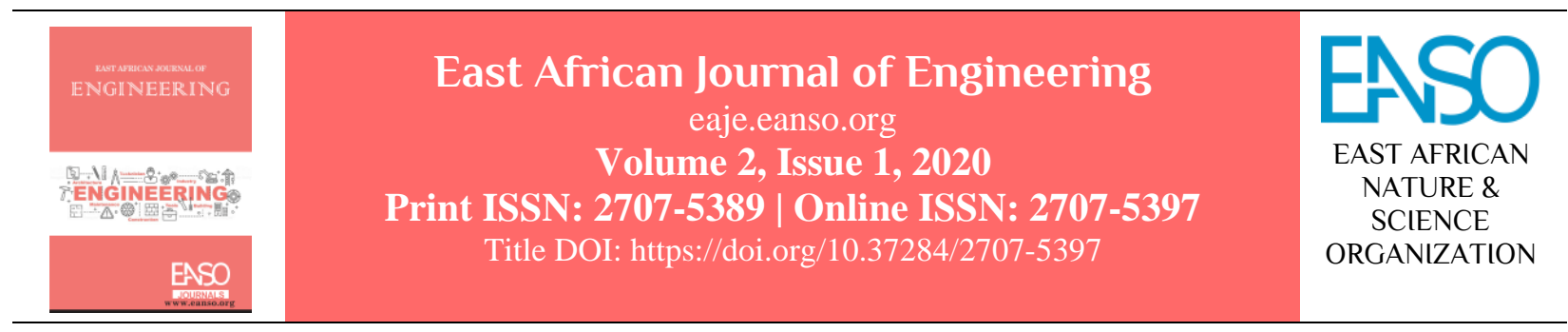

Original Article

\title{
The Role of the National Construction Authority in the Conservation of Vernacular Architectural Heritage
}

\author{
Mugwima B. Njuguna, PhD ${ }^{* 1}$, Ephraim W. Wahome, PhD ${ }^{2} \&$ Anne Marie Deisser, PhD ${ }^{3}$ \\ ${ }^{1}$ Architect; Senior Lecturer at the Centre for Urban Studies, Jomo Kenyatta University of Agriculture \& Technology; Director, \\ Centre for Urban Studies. \\ ${ }^{2}$ Conservator; Associate Professor in the Department of History and Archaeology, University of Nairobi; Associate Dean, Faculty \\ of Arts, University of Nairobi \\ ${ }^{3}$ Conservator; Research Affiliate in the Department of History and Archaeology, University of Nairobi; Honorary Research \\ Associate, Institute of Archaeology, University College London \\ *Author for Correspondence Email: mugwima@gmail.com or mugwima@sabs.jkuat.ac.ke.
}

Article DOI: https://doi.org/10.37284/eaje.2.1.178

\section{Publication Date: ABSTRACT}

$10 \mathrm{Jul} 2020$ Vernacular architecture is a malleable concept that encompasses structures

Keywords: produced by empirical/ experiential builders. It is sometimes referred to as indigenous, primitive, ethnic or even architecture without architects. Vernacular architectural heritage often found in rural areas and historic urban areas and villages represent a cultural heritage that has been handed down from one generation to the next. This heritage is under threat from modernising forces which cause deterioration in cultural and historical continuity. It is important to conserve this architecture and associated technologies for posterity. Both tangible and intangible heritage of vernacular architecture is threatened through blatant negligence, emergent and more profitable modes of construction, and lack of funds for minimum maintenance. To a large extent, this heritage is quickly deteriorating and disappearing into the hands of vandals and illegal traders due to the lack of appropriate conservation, sensitisation and training for the public and heritage professionals in the conservation of materials and practices. The paper explores the vernacular heritage in Kenya, the state of its conservation and the risks associated with its conservation. It is argued that since NCA is mandated inter alia to undertake research into any matter relating to the construction industry, it should complement the efforts of the National Museums of Kenya in the conservation of cultural heritage in so far as materials and building technologies are concerned. There is no clear legal framework for the conservation of vernacular architecture in place and it is often lumped together with other popular forms of architecture which have well-defined and documented historical trends. Emphasis has been on urban architecture in Kenya. The paper established that vernacular heritage has only 
been haphazardly conserved, with no clear management, documentation and preservation policies. The paper found that no resources are specifically set aside for the conservation of these heritages. The theoretical analysis concludes that vernacular architecture in Kenya has been neglected and exposed to deterioration. It also points out that the level of public sensitisation on the heritage is low and its conservation and management needs have been ignored. The study, therefore, recommends public sensitisation, preventive and interventive conservation and appropriate policies to save the heritage from imminent loss. It further suggests that detailed documentation of vernacular building materials and technology should be undertaken as a matter of urgency.

\section{APA CITATION}

Njuguna, M., Wahome, E., \& Deisser, A. (2020). The Role of the National Construction Authority in the Conservation of Vernacular Architectural Heritage. East African Journal of Engineering, 2(1), 23-32. https://doi.org/10.37284/eaje.2.1.178

\section{CHICAGO CITATION}

Njuguna, Mugwima, Ephraim Wahome, and Anne Deisser. 2020. "The Role of the National Construction Authority in the Conservation of Vernacular Architectural Heritage". East African Journal of Engineering 2 (1), 23-32. https://doi.org/10.37284/eaje.2.1.178.

\section{HARVARD CITATION}

Njuguna, M., Wahome, E. and Deisser, A. (2020) "The Role of the National Construction Authority in the Conservation of Vernacular Architectural Heritage”, East African Journal of Engineering, 2(1), pp. 23-32. doi: 10.37284/eaje.2.1.178.

\section{IEEE CITATION}

M. Njuguna, E. Wahome, and A. Deisser, "The Role of the National Construction Authority in the Conservation of Vernacular Architectural Heritage", EAJE, vol. 2, no. 1, pp. 23-32, Jul 2020.

\section{MLA CITATION}

Njuguna, Mugwima, Ephraim Wahome, and Anne Deisser. "The Role of the National Construction Authority in the Conservation of Vernacular Architectural Heritage". East African Journal of Engineering, Vol. 2, no. 1, Jul 2020, pp. 23-32, doi:10.37284/eaje.2.1.178.

\section{INTRODUCTION}

Vernacular architecture is a malleable concept that encompasses structures produced by empirical/ experiential builders. It is sometimes referred to as indigenous, primitive, ethnic or even architecture without architects. Vernacular architectural heritage often found in rural areas and historic urban areas and villages represent a cultural heritage that has been handed down from one generation to the next. This heritage is under threat from modernising forces which cause deterioration in cultural and historical continuity. It is important to conserve this architecture and associated technologies for posterity.

The loss of vernacular heritage is daily evidenced in the Kenyan built environments. For example, the variety and complexity that is inherent in vernacular constructions in historic cities in is being replaced by out of scale high-rise accommodation (Barton, Grant \& Guise, 2003; Avrami, 2000; Tibbalds, 1992; King \& Procesi, 1990). Changing living standards compel inhabitants of rural areas also to radically alter their vernacular architecture. When such changes occur, whether, in the rural or urban areas, new spatial patterns emerge that lead to both visual and functional contradictions, such as inappropriate scale and colour (Forsyth, 2007a; Feilden, 2003; Fitch, 1990). These contradict the traditions and cultural heritage of a community. Discordant architectural forms supplant and destroy the original character, thus falsifying the authentic aesthetic experience. The genius loci are lost. Fitch (1990) ably argues:

'that the efflorescence of internationalised prototypes has serious consequences since these imported architectural artefacts are illadapted to a foreign environment and depend on the importation of high technology from the 
West, itself a very expensive operation and therefore not economically sustainable' (p. 8).

Due to the fact that new and fancy buildings are perceived to be superior, they cause a disturbing feeling of private well-being among perceived public squalor and this could cause unprecedented segregation of classes and ethnic groups. The disruption in the 'continuity of experience leads to placeless-ness and rootlessness' (Elkadi, 2007, p. $5)$.

The professionals' decisions regarding the conservation of vernacular architecture, particularly in historic cities are within the philosophical framework of procedural planning (Lang, 1988) and do not take into account factors that may be important to the local community and therefore propagate the exclusion of the local perceptions. This precipitates a catastrophe to the heritage commons. This distinctiveness produced through vernacular architecture has been recognised as the concrete reality humans have to face and come to terms within their daily life (Norberg-Schulz, 1980). Local distinctiveness is an important value that makes a place unique from another (Orbasli, 2008; Nasar, 1998; 2000).

\section{WHY CONSERVATION?}

The urge to conserve vernacular architecture 'derives from several interrelated presumptions: that the past was unlike the present, that its relics are necessary to our identity and desirable in themselves; and that tangible remains are finite and a dwindling commodity' (Lowenthal, 1985, p. 389). Vernacular architecture is an important cultural property requiring protection and enhancement. According to Lowenthal (1985), the past is omnipresent and collectively immortal, and the surviving past's most essential and pervasive benefit is to render the present familiar and comprehensible, thus making surroundings comfortable. Therefore, the conservation of vernacular built heritage is critical as a repository of community knowledge, system and values.

Conservation of the past heritage has instructive parallels that can be used as a guide to current developments by drawing from the saturations of time. This will preserve traditional skills and craftsmanship, create new employment opportunities for artists, craftsmen, architects, technologists, and encourage business promotion through specialised construction activities amongst the contractors, developers, material suppliers and traders. The benefits of tourism would also be reaped, in addition to improving the socialeconomic picture of the country.

The conservation of architectural heritage encompasses various aspects of building conservation and planning combined with social, economic and functional considerations (Orbaşli, 2008; Feilden, 1979; 2003). Conservation is commonly carried out on historic buildings. A historic building can be considered as one 'that gives a sense of wonder and makes us want to know more about the people and culture that produced it' (Feilden, 1994, p. 1). Such a building has architectural, aesthetic, historical, documentary, archaeological, economic, social and even political and spiritual values. As explained by Feilden (1994), its first impact is always emotional, for it is a symbol of cultural identity and continuity.

According to Feilden (1994), conservation may be defined as 'the action taken to prevent decay' (p. 3). It embraces all acts that prolong the life of our cultural and natural heritage in order to ensure the continuous transmission of artistic and human messages. Feilden further indicates that the basis of all conservation is legislation. Sarkar $(1996,1994)$ takes conservation to be the most generally acceptable and inclusive term to cover the breadth of activities aimed at safeguarding heritage for the future through wise use and deliberate intervention in order to control the rate of change. Dobby (1979) argues that conservation addresses itself to the tangible and the physical amid a horde of planning imponderables and is bound to the continuation of past buildings although altered in varying degrees for the sake of posterity.

Orbaşli (2008) has shown conservation to involve 'maintaining the character of a historic quarter while still allowing it to evolve as a place to live in' (p. 6). Further conservation can be taken as the process of managing change while development is the mechanism that delivers change (Orbaşli, 2008; Sarkar, 1996). Tschudi-Madsen (1985) is cited by Roders (2007) observing that the word conservare 
in Latin is derived from the prefix con which can mean together with and often has strengthening effect, and servare, which means to protect, to guard, to save' (p. 158). In line with this, Orbaşli (2008) has emphasised that conservation is about the people and that approaches to conservation will be linked to values of the society at that time and 'the role of the conservation professional is to make balanced judgements that will help maintain the continuity of buildings and townscapes while serving present-day communities and their needs' (p. 6). Conservation must, therefore, garner public support for it to be sustainable. Conservation of the built heritage covers all circumstances from absolute retention to demolition, for sometimes partial or complete demolition may be necessary for the benefit of the overall project (Roders, 2007; Highfield, 1991, 1987).
The various degrees of change in interventions illustrated in Table 1 below are also regarded as approaches to conservation (Orbaşli, 2008). Several of these approaches are defined in the Venice Charter (ICOMOS, 1964), a philosophical manifesto produced by the International Congress for Conservation in Venice in 1964. Similarly, the Burra Charter (ICOMOS, 1999) having regard to the Venice Charter expanded these approaches. Feilden (1994, 1979) argued that conservation involves making interventions at various scales and levels of intensity, which are determined by the physical condition, causes of deterioration, and anticipated future environment of the cultural property under treatment. These interventions or approaches must be considered both holistically and individually.

Table 1: Degree of Change in Interventions in Historic Areas and Historic Buildings

\begin{tabular}{|c|c|c|c|c|}
\hline \multicolumn{5}{|c|}{ Change } \\
\hline Action & None & Some & Much & Total \\
\hline Cleaning & & & & \\
\hline Repair & & & & \\
\hline Preservation & & & & \\
\hline Enhancement & & & & \\
\hline Conservation & & & & \\
\hline Restoration & & & & \\
\hline Rehabilitation & & & & \\
\hline Reconstruction & & & & \\
\hline Demolition & & & & \\
\hline
\end{tabular}

Source: Adapted from Feilden (1994); Dobby (1978).

In his Contemporary Theory of Conservation, Viňas (2005) does not relate conservation to the truth but to meanings. These meanings from a theoretical point of view, give the rationale for conservation:

- To preserve or improve the scientific meanings of an object

- To preserve or improve the social, hi-cult symbolic meanings that an object has for large groups

- To preserve or improve the sentimental symbolic meanings that an object has for small groups or even individuals (p. 175)
These reasons are not mutually exclusive. Classical theories of conservation, generally taken as the approaches to conservation and based on the notion of the pursuit of truth, cannot cope with these communicative phenomena, which are outside their conceptual frames. For as Cosgrove (1994), 'it is the act of conservation itself that makes an object part of cultural heritage, not the cultural heritage that demands conservation' (Viňas, 2005, p. 176).

The legion of benefits the past provides clearly transcends nostalgia. Freud cited in Bernfeld (1951) stated that 'only a good-for-nothing is not interested in the past' (Lowenthal, 1985, p. 35). Conservation is important because of the charm of the past (Wilde, 1981). The concept of national heritage is equally affable and is occasionally evoked for the 
purposes of justifying conservation so that the connection with a treasured past is maintained (Sarkar, 1996; 1994).

Dobby (1978) identified associational and psychological needs that derive from the concept of symbolism as further reasons for conservation. He further identifies a history, artistic design, and associations as the other grounds for conservation. The conservation of historical heritage is integral to our sense of identity. Ability to recall and identify with our past gives existence meaning, purpose and value (Norberg-Schulz, 1980). Furthermore, conservation can be for pedagogical reasons. We can learn from the past and this might 'enable men to foretell, if not to forestall, the future' (Lowenthal, 1985; p. 46). Conservation also provides relics for contemplation and these treasures of the past are enriching.

The conservation of cultural property demands the management of resources and a good sense of proportion. Objects are chosen for treatment and the degree of intervention are predicated upon the values that can be assigned to cultural property. The values provide a framework for systematically setting the overall priorities in the scheduling of interventions. These values can be grouped into three, namely:

a) 'Cultural Values: documentary value, historical value, archaeological and age value, aesthetic value, architectural value, townscape value, landscape and ecological value;

b) Use Values: functional value, economic value, social value and political value;

c) Emotional Values: wonder, identity and continuity' (Feilden, 1979, p. 22).

The values identified above are by no means exhaustive. Other values identified are 'intended as an overview and starting point when embarking on a conservation project' (Orbaşli, 2008, p. 40). Age and rarity value concern the fact that the older a structure or a neighbourhood is, the more value is likely to be attached to it. Rarity also relates to the occurrence of a building type or technique. Vernacular architectures have exemplary qualities of design and high quality of craftsmanship and therefore have high architectural and artistic value (de-la Torre, 2002; Feilden \& Jokilehto, 1998; Feilden, 1994).

The associative value is the association a place has with an event or personality in history (Feilden, 1994). Places of war, e.g. battlefields, have a high associative value, even if there is no structure on site. They also possess emotional and spiritual values. We can learn a lot from vernacular heritage, including their history, social relations and construction techniques and thus educational value are inculcated in us. Other values identified by Orbaşli are emotional values, historical values, landscape value, local distinctiveness, political value, public value, religious and spiritual value, scientific research and knowledge value, social value, symbolic value, economic, technical value and townscape value (Orbaşli, 2008, p. 38-46). Feilden $(1994,1979)$ recommended that the cost of conservation be allocated partially to each of the values in order to justify the total costs to the community.

\section{Charter on the Built Vernacular Heritage (1999)}

This charter was ratified by the ICOMOS 12th General Assembly, in Mexico, October 1999. According to the charter:

...the built vernacular heritage occupies a central place in the affection and pride of all peoples. It has been accepted as a characteristic and attractive product of society. It appears informal, but nevertheless orderly. It is utilitarian and at the same time, possesses interest and beauty. It is a focus of contemporary life and at the same time a record of the history of society. Although it is the work of man it is also the creation of time. It would be unworthy of the heritage of man if care were not taken to conserve these traditional harmonies, which constitute the core of man's own existence. The built vernacular heritage is important; it is the fundamental expression of the culture of a community, of its relationship with its territory and, at the same time, the expression of the world's cultural diversity. The vernacular building is the traditional and natural way by which communities house themselves. It is a continuing process including necessary 
changes and continuous adaptation as a response to social and environmental constraints. The survival of this tradition is threatened worldwide by the forces of economic, cultural and architectural homogenisation. How these forces can be met is a fundamental problem that must be addressed by communities and also by governments, planners, architects, conservationists and by a multidisciplinary group of specialists. Due to the homogenisation of culture and of global socio-economic transformation, vernacular structures all around the world are extremely vulnerable, facing serious problems of obsolescence, internal equilibrium and integration. It is necessary, therefore, in addition to the Venice Charter, to establish principles for the care and protection of our built vernacular heritage (ICOMOS, 1999).

The charter further argues that the appreciation and successful protection of the vernacular heritage depend on the involvement and support of the community, continuing use and maintenance. Governments and responsible authorities are urged to recognise the right of all communities to maintain their living traditions, to protect these through all available legislative, administrative and financial means and to hand them down to future generations. This is an opportune moment where the NCA can complement the efforts of NMK. The charter on enumerates the following principles to be used as a guide in the conservation of vernacular architecture.

1. The conservation of the built vernacular heritage must be carried out by multidisciplinary expertise while recognising the inevitability of change and development, and the need to respect the community's established cultural identity.

2. Contemporary work on vernacular buildings, groups and settlements should respect their cultural values and their traditional character.

3. The vernacular is only seldom represented by single structures, and it is best conserved by maintaining and preserving groups and settlements of a representative character, region by region.
4. The built vernacular heritage is an integral part of the cultural landscape and this relationship must be taken into consideration in the development of conservation approaches.

5. The vernacular embraces not only the physical form and fabric of buildings, structures and spaces, but the ways in which they are used and understood, and the traditions and the intangible associations which attach to them.

Feilden (1994) suggests that any proposed intervention should:

1) be reversible or repeatable, if technically possible, or

2) not prejudice future intervention whenever this may become necessary;

3) not hinder the possibility of later access to all evidence incorporated in the object;

4) allow the maximum amount of existing material to be retained;

5) be harmonious in colour, tone, texture, form and scale, if additions are necessary, but should be less noticeable than the original material, while at the same time being identifiable;

6) not to be undertaken by conservators/ restorers who are insufficiently trained or experienced, unless they obtain competent advice. However, it must be recognised that some problems are unique and have to be solved from first principles by trial and error basis (p. 6).

Due to the fundamental differences between the conservation of built heritage and the conservation of the arts, a wise application of the principles is called for. Architectural conservation of buildings, and more so of urban heritage areas, involves the site, setting, the people resident therein and the general physical environment (Forsyth, 2007b; Feilden \& Jokilehto, 1998; Sarkar, 1996; Feilden, 1994). 


\section{CONSERVATION OF VERNACULAR ARCHITECTURE IN KENYA}

The conservation of heritage sites in Kenya is governed by the National Museums and Heritage Act of 2006. The National Museums and Heritage Act of 2006 is the most current of a series of documents that govern conservation. This is an:

'Act of Parliament to consolidate the law relating to national museums and heritage; to provide for the establishment, control, management and development of national museums and the identification, protection, conservation and transmission of the cultural and natural heritage of Kenya; to repeal the Antiquities and Monuments Act and the National Museums Act; and for connected purposes' (GOK, 2006, p. 128).

The National Museums and Heritage Act of 2006 provide for the establishment, functions and the powers of the National Museums of Kenya, a body corporate. Specifically, the National Museums shall:

1) Serve as national repositories for things of scientific, cultural, technological and human interest;

2) Serve as places where research and dissemination of knowledge in all fields of scientific, cultural, technological and human interest may be undertaken;

3) Identify, protect, conserve and transmit the cultural and natural heritage of Kenya; and,

4) Promote cultural resources in the context of social and economic development (GOK, 2006, p. 135-136).

It is clear that the National Museums of Kenya is the legally mandated body to undertake conservation of vernacular built heritage in the country. However, it has no capacity to either plan or supervises the implementation of any plan that it may undertake or that may be undertaken on its behalf by other parties. Emphasis has been on the architectural heritage of the grand tradition at the expense of other heritages. Little effort at conserving the vernacular heritage of the nation has been undertaken by National Museums of Kenya. The practical defect of the conservation law is that emphasis has been on the conservation of the urban built heritage at the expense of other heritages. Indeed, there is no training at all in the conservation of vernacular heritage in Kenya, especially as appertains to the architectural profession. Conservation of the natural and cultural heritage is not given sufficient resources when compared to other endeavours such as defence and education. Because of resource scarcity, the NMK is understaffed.

The custodians of the vernacular heritage are not also adequately involved in its conservation. They are reduced to mere spectators in the conservation of their own heritage and are simply sometimes employed as mere labourers in the process. Community participation is at the end of the projects when fundamental decisions have already been made.

The production of vernacular heritage, by and large, involves the construction of buildings, which falls within the purview of the NCA. The National Construction Authority, NCA, is established under the National Construction Act, which is 'Act of Parliament to provide for the establishment, powers and functions of the National Construction Authority and for connected purposes' (GOK, 2011).

The Act defines "construction works" as

... the construction, extension, installation, repair, maintenance, renewal, removal, renovation, alteration, dismantling, or demolition of-

(a) any building, erection, edifice, structure, wall, fence or chimney, whether constructed wholly or partly above or below ground level (p. 5).

NCA is mandated to:

...(a) promote and stimulate the development, improvement and expansion of the construction industry; undertake or commission research into any matter relating to the construction industry; provide, promote, review and coordinate training programmes organised by 
public and private accredited training centres for skilled construction workers and construction site supervisors (GOK, 2011, p. 7.)

From the foregoing, NCA has its role clearly cut out.

\section{CONCLUSION}

The NCA should liaise with the NMK and draw up a conservation strategy that will involve the following:

a) Need for cultural heritage mapping, backed by NCA. A survey of all vernacular heritage should be undertaken. Historical research and analysis supported by photographic records should be undertaken by heritage professionals in coordination with architects and the support of the NCA.

b) A team of architecture and heritage professionals should develop local conservation principles and practices. The team should consist of administrator or owner, archaeologists, architects, art/ architectural historians, sociologists, anthropologists, contractors, conservators, civil, mechanical, and electrical engineers, environmental engineers, historic garden engineers master craft worker, material scientist, quantity surveyor, town planner and curator.

c) A compendium of vernacular architecture should be developed by the NCA with collaboration from the Nationals museums of Kenya. The NMK may then choose what needs to be gazetted for posterity.

d) The training of specialised skills necessary in the conservation of this living vernacular heritage should be developed with the support of the NCA and international organisations such as ICOMOS, ICCROM, TERRA etc. Such training would involve different craftsmen, artisans and representatives of the local community involved.

e) Immediate protection against the decay of vernacular architecture by a committee selected by NCA, the local community, NMK, and county representatives.

f) Creation of model houses and villages across the country. Such houses could be replicas.

From the foregoing, it can be seen that vernacular architecture is a unique heritage, from both local and international perspectives. It is a global common. It is a useful tool for Kenyan architects, essential for local communities and characteristic of local values linked to history, social, economic and even religious values. In tandem, NCA and NMK can cause sustained conservation.

\section{REFERENCES}

Avrami, E. (2000). Values and heritage conservation. Conservation: The Getty Conservation Institute Newsletter, 15(2), 1821.

Barton, H., Grant, M., \& Guise, R. (2003). Shaping Neighbourhoods: a guide for health, sustainability and vitality. London: Spon Press.

Bernfeld, S. C. (1951). Freud and archeology. American Imago, 8(2), 107-128.

Cosgrove, D. E. (1994). Should We Take it so Seriously? In W.E. Krumbein, P. Brimblecomb, D. E. Cosgrove \& S. Staniforth (Eds), Durability and Change. Science, Responsibility, and Cost of Sustaining Cultural Heritage. (pp. 259-266). Chichester: John Wiley and Sons.

de-la Torre, M. (Ed.). (2002). Assessing the Values of Cultural Heritage. Los Angeles, C.A. The Getty Conservation Institute.

Dobby, A. (1978). Conservation and Planning. London: Hutchinson and Co. Ltd.

Elkadi, H. A. (2006). Valuing local built heritage in a global setting: Identity \& visual perceptions of cultural built heritage in Northern Ireland. In Cultural Landscapes in the 21st Century Forum UNESCO: University and Heritage 10th International Seminar and Inter-Congress of the World Archaeological Congress. Newcastle upon Tyne: United Nations 
Educational, Scientific and Cultural Organization (UNESCO).

Feilden, B. M. (1979). An introduction to Conservation of Cultural Property. Rome: ICCROM.

Feilden, B. M. (1994). Conservation of Historic Buildings. Johannesburg: Reed Educational and Professional Publishing Ltd.

Feilden, B. M. (2003). Conservation of Historic Buildings. Oxford: Architectural Press, Elsevier.

Feilden, B. M., Jokilehto, J. (1998). Management Guidelines for World Cultural Heritage Sites. Rome: ICCROM.

Fitch, J. M. (1990). Historic Preservation: Curatorial Management of the Built World. Virginia: The University of Virginia Press.

Forsyth, M. (2007a). The Past in the Future. In Forsyth, M. (Ed.), Understanding Historic Building Conservation (pp. 1-8). Oxford: Blackwell Publishing.

Forsyth, M. (Ed.). (2007b). Understanding Historic Building Conservation. Oxford: Blackwell Publishing.

Government of Kenya (GOK). (2006). The National Museums and Heritage Act. Nairobi: Government Press.

Government of Kenya (GOK). (2011). The National Construction Authority Act. Nairobi: Government Press.

Highfield, D. (1987). Rehabilitation and Re-use of Old Buildings. London: E \& F.N. Spon.

Highfield, D. (1991). The Construction of New Buildings Behind Historic Façades. London: Spon.

ICOMOS. (1964). Venice Charter. Retrieved from International Council on Monuments and Sites (ICOMOS), available at http://www.icomos.org/venice_charter.html
ICOMOS. (1999). Burra Charter. Retrieved from International Council on Monuments and Sites (ICOMOS), available at http://www.icomos.org/australia/burra.html

ICOMOS. (1999). Charter on the Built Vernacular Heritage. Retrieved from International Council on Monuments and Sites (ICOMOS), available at http://www.icomos.org/charters/vernacular_e. pdf

King, J., Procesi, D. (1990). A Conservation Plan for the Old Town of Mombasa, Kenya. Mombasa: Municipal Council \& National Museums of Kenya.

Lang, J. (1988). Symbolic Aesthetics in architecture: Toward a Research Agenda. In J. K. Nasar (Ed.), Environmental Aesthetics. Theory, Research and Applications (pp. 11-26). New York: Cambridge University Press.

Lowenthal, D. (1985). The Past is a Foreign Country. Cambridge: Cambridge University Press.

Nasar, J. L. (1998) The Evaluative Image of the City. Thousand Oaks, CA: Sage.

Nasar, J. L. (2000). The Evaluative Image of Places. In Walsh, W. B., Craik, K. H., Price, R. H. (Eds), Person-Environment Psychology: New Directions and Perspectives (pp. 117168). Mahwah, N.J.: Lawrence Erlbaum Associates, Inc.

Norberg-Schulz, C. (1980). Genius Loci: Towards a Phenomenology of Architecture. In Cody, J. \& Siravo, F. (Eds), Historic Cities: Issues in Urban Conservation. Los Angeles, CA: Getty Conservation Institute.

Orbaşli, A. (2008). Architectural conservation: principles and practice. Oxford: Blackwell Science Ltd.

Roders, P. A. (2007). Re-Architecture: Lifespan Rehabilitation of Built Heritage. Eindhoven: Bouwstenen Publicatieburo.

Sarkar, I. (1994). Conservation Scenario in Kenya. Centre for Built Environment at Calcutta. 
East African Journal of Engineering, Volume 2, Issue 1, 2020

Article DOI: https://doi.org/10.37284/eaje.2.1.178

Sarkar, I. (1996). A Study on Conservation IssuesDoes, our Past, Have a Future? Unpublished Report.

Tibbalds, F. (1992). Making people-friendly towns: Improving the public environment in towns and cities. London \& New York: Spon Press.

Tschudi-Masden, S. (1985). Principles in Practice. Bulletin of the Association of Preservation
Technology. (Association for Preservation Technology International). 17 (3/4), 12-20.

Viňas, M. S. (2005). Contemporary Theory of Conservation. London: Elsevier.

Wilde, O. (1981). The Picture of Dorian Gray. London: Dent.

\section{APPENDIXES}

\section{Appendix I: Examples of vernacular architecture in Kenya}

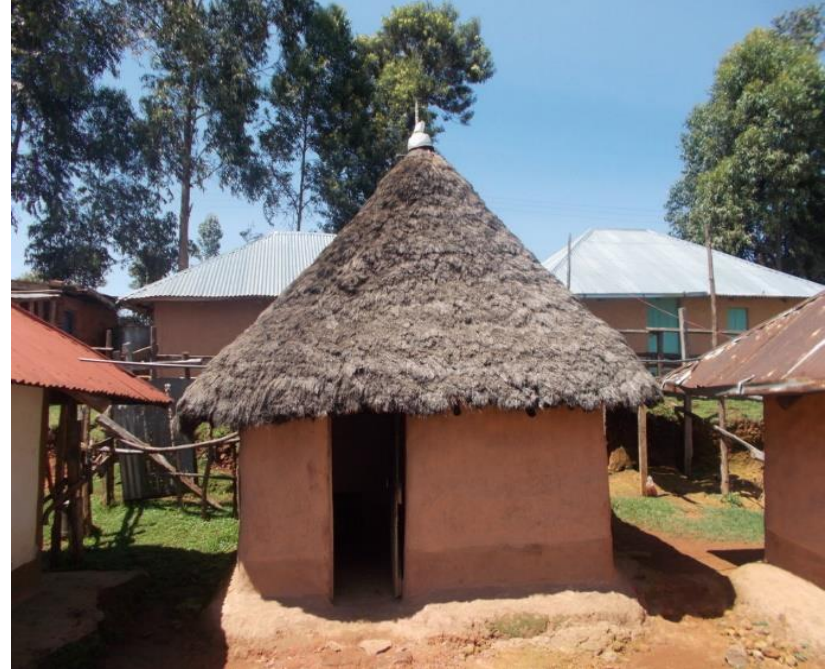

House in Kisii

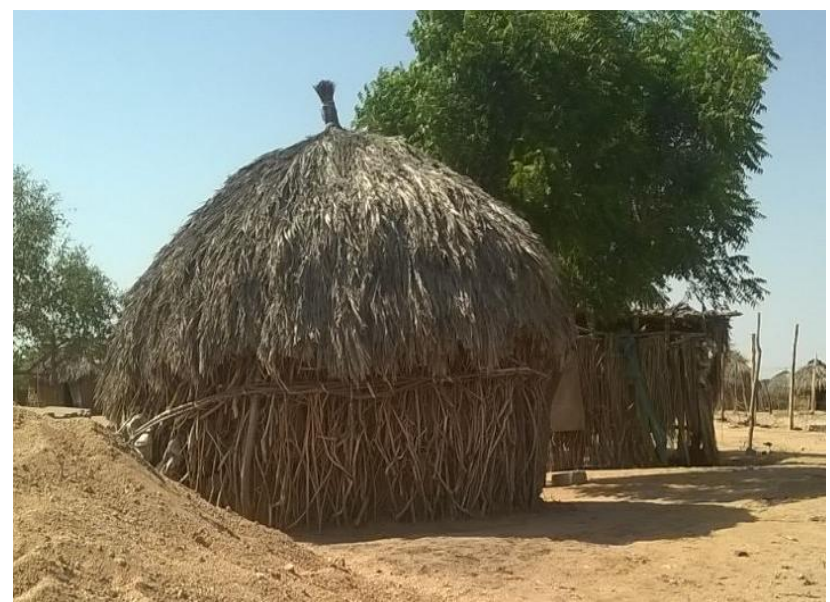

House in Turkana

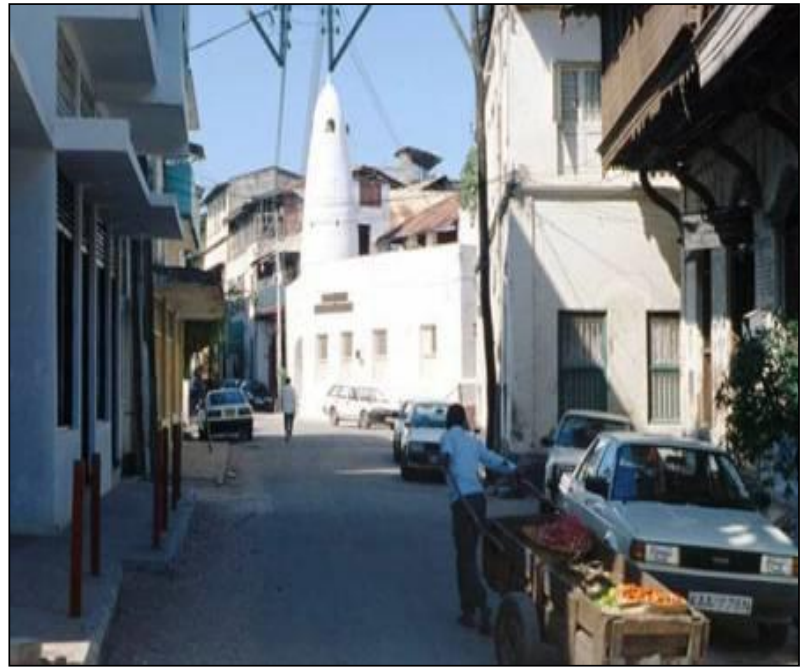

Old Town of Mombasa

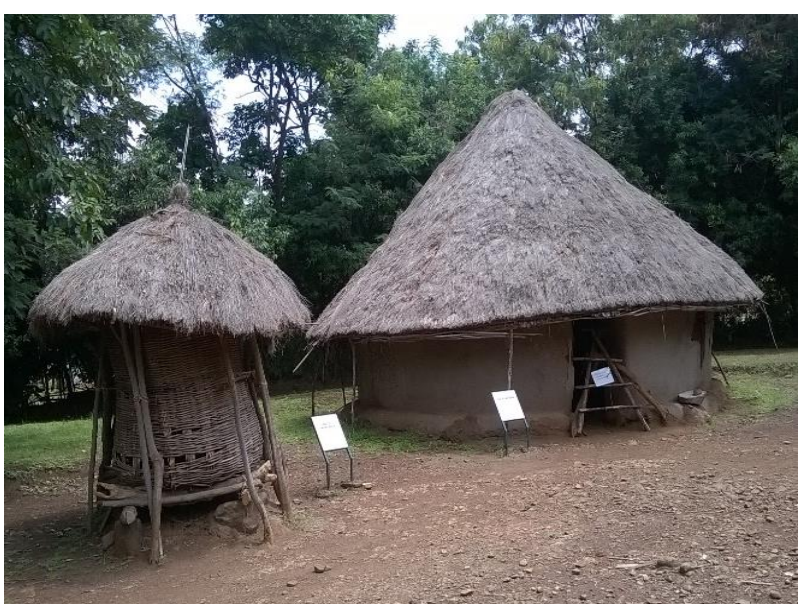

Conservation efforts: Luo Architecture at Kisumu Museum 